\title{
Soft Tissue Sarcoma of the Trunk and Extremities Pathologic Regional Lymph Nodes TNM Finding v8
}

National Cancer Institute

\section{Source}

National Cancer Institute. Soft Tissue Sarcoma of the Trunk and Extremities Pathologic Regional Lymph Nodes TNM Finding v8. NCI Thesaurus. Code C136689.

A pathologic finding about one or more characteristics of soft tissue sarcoma of the trunk and extremities, following the rules of the TNM AJCC v8 classification system as they pertain to staging of regional lymph nodes. 